\title{
Utilization of Steel Slag in Agriculture (Review)
}

\author{
Rina Devnita, Apong Sandrawati, dan Mahfud Arifin \\ Departemen Ilmu Tanah dan Sumberdaya Lahan, Fakultas Pertanian Universitas Padjadjaran \\ Jl. Raya Bandung Sumedang Km 21, Jatinangor \\ Korespondensi: rinabursi@yahoo.com
}

\begin{abstract}
The process of refining iron by Blast Furnace (BF) or Electric Arc Furnace (EAF) produces steel and by-product: steel slag. This by-product can be used for various fields such as construction, industry and agriculture. This paper aimed to discuss the use of steel slag in agriculture as fertilizer, lime and ameliorant in the soils. The content of elements and compounds in steel slag is the basic component for the utilization of this material, therefore they are displayed quite completely. The presence of other contents like of heavy metals which are classified as hazardous toxic materials is also stated. Utilization of steel slag for agriculture has been carried out widely in various countries such as Japan, Germany and the United States. There have been many studies of steel slag in Indonesia that prove the benefits of steel slag in adding nutrients and improving soil reactions. However, the use of this material is still limited to research field, has not been widely used. Meanwhile, many research has proven that steel slag can improve some chemical characteristics like $\mathrm{pH}$ and CEC, as well improve $\mathrm{Ca}, \mathrm{Mg}$ and Si content. Steel slag can release P from retention and fixation and Andisols and Ultisols. Research showed that steel slag improved the yield of rice, maize, horticultural and industrial plants.
\end{abstract}

Keywords: silicate, phosphate, calcium carbonate, hazardous, variable charge soils

\section{INTRODUCTION}

Steel slag is a by-product of the iron refining process in the steel industry. The refining process produces pure steel with steel slag as a by-product which can still be utilized for various uses including the cement industry, road construction, bridges and buildings, and agriculture. Steel slag is used for agriculture due to contains $\mathrm{Ca}, \mathrm{Mg}$ and $\mathrm{Si}$, and therefore is potential to be used as fertilizer and ameliorant. Those elements are derived from the iron refining process due to the steel industry requires the addition of various materials.

Steel is produced from iron ore, basically iron oxide and is processed in furnaces (Wright, 2011). The materials fed into the heating furnace are iron ore itself, carbon, calcium oxide. calcium carbonate and calcium magnesium carbonate. In the process, hot air is flowed into the smelting process where all materials are completely burned, resulting in a series of reactions that produce carbon dioxide $\left(\mathrm{CO}_{2}\right)$, iron $(\mathrm{Fe})$, calcium oxide $(\mathrm{CaO})$ and calcium silicate $\left(\mathrm{Ca}_{2} \mathrm{SiO}_{4}\right)$. These processes and reactions occur continuously. Iron ore is refined into steel and steel slag is produced as a by-product.

Steel is produced using one of two methods: Blast Furnace/BF and Electric Arc Furnace/EAF (Yildirim and Prezzi, 2011). The blast furnace was the first method of producing steel from iron oxide, introduced in the 14th century, and produced one thousand kilograms steel per day. Blast Furnace technology and equipment are increasingly developing until now, and they are becoming more modern. The steel produced per day is much higher. However, the process in the Blast Furnace remains the same, namely using coke (coal that has been cooked), iron ore and limestone to produce pig iron which is then processed into steel.

Electric Arc Furnace (EAF) technology emerged at the end of the 19th century. The use of EAF has expanded and now accounts for a large proportion of the world's steel production. EAF technology differs from Blast Furnace in that EAF uses electric current to melt scrap metal or scrap steel to produce molten steel. 
The main content of steel slag in general is lime $(\mathrm{CaO})$ and silica $\left(\mathrm{SiO}_{2}\right)$. Other components are iron oxide $\left(\mathrm{Fe}_{2} \mathrm{O}_{3}\right)$, aluminum oxide $\left(\mathrm{Al}_{2} \mathrm{O}_{3}\right)$, magnesium oxide ( $\mathrm{MgO})$, manganese oxide (MnO), and phosphate in the form of $\mathrm{P}_{2} \mathrm{O}_{5}$ (Seti'en et al., 2009). Steel slag also contains smaller amounts of various other materials. Heavy metals are also found in steel slag in small concentrations. Although, some of them are categorized as toxic and hazardous materials (Das et al., 2007).

The main content of steel slag (in percentage, \%) from various steel mills in the world is obtained from various sources. The factory in Poland contain $\mathrm{CaO}$ (27.46), $\mathrm{SiO}_{2}$ (16.69), $\mathrm{Fe}_{2} \mathrm{O}_{3}$ (33.82), $\mathrm{Al}_{2} \mathrm{O}_{3}$ (6.64), $\mathrm{MgO}$ (6.68), $\mathrm{MnO}$ (3.87), $\mathrm{P}_{2} \mathrm{O}_{5}$ (0.30) (Sas et al., 2015). Manufacturers in Japan contain $\mathrm{CaO}$ (41.7), $\mathrm{SiO}_{2}$ (33.8), $\mathrm{Fe}_{2} \mathrm{O}_{3}$ (0.4), $\mathrm{Al}_{2} \mathrm{O}_{3}$ (13.4), $\mathrm{MgO}$ (7.4), $\mathrm{MnO}(0.3), \mathrm{P}_{2} \mathrm{O}_{5}(<0.1)$ (Nippon Slag Association, 1978). Steel mills in Indonesia Krakatau Steel contain $\mathrm{CaO}$ (42.0), $\mathrm{SiO}_{2}$ (12.50), $\mathrm{Fe}_{2} \mathrm{O}_{3}$ (30.81), $\mathrm{Al}_{2} \mathrm{O}_{3}$ (5.12), $\mathrm{MgO}$ (6.00), $\mathrm{MnO}$ (1.6), $\mathrm{P}_{2} \mathrm{O}_{5}$ (0.50) (Devnita et al., 2017a). Steel mills in the United States contain $\mathrm{CaO}$ (39.40), $\mathrm{SiO}_{2}$ (11.97), $\mathrm{Fe}_{2} \mathrm{O}_{3}$ (30.23), $\mathrm{Al}_{2} \mathrm{O}_{3}$ (2.16), $\mathrm{MgO}$ (9.69), $\mathrm{MnO}$ (2.74), $\mathrm{P}_{2} \mathrm{O}_{5}$ (1.00) (Yildirim and Prezzi, 2011). Meanwhile, steel mills in China contain $\mathrm{CaO}$ (40.30), $\mathrm{SiO}_{2}$ (15.38), $\mathrm{Fe} 2 \mathrm{O} 3$ (12.73), $\mathrm{Al}_{2} \mathrm{O}_{3}$ (2.54), $\mathrm{MgO}$ (9.05), $\mathrm{MnO}$ (1.88), $\mathrm{P}_{2} \mathrm{O}_{5}$ (1.01) (Bing et al., 2019).

The steel slag content comes from the Blast Furnace (BF) or Electric Arc Furnace (EAF) process, produces components with approximately the same concentration. $\mathrm{CaO}$, $\mathrm{SiO}_{2}$ and $\mathrm{Fe}_{2} \mathrm{O}_{3}$ are the compounds with the highest concentrations, followed by $\mathrm{Al}_{2} \mathrm{O}_{3}$, $\mathrm{MgO}, \mathrm{MnO}$ and $\mathrm{P}_{2} \mathrm{O}_{5}$ with less concentrations. Except for aluminum (Al), the main contents in steel slag are nutrients, causes steel slag can be used as fertilizer. Nevertheless, the presence of $\mathrm{Al}$, a toxic element for plants, must be considered in the application of steel slag. The presence of $\mathrm{Fe}_{2} \mathrm{O}_{3}$ and $\mathrm{MnO}$ should also to be cared. Iron and $\mathrm{Mn}$ are elements needed by plants, but their needs are only in small (micro) quantities, therefore these elements need attention when applied to plant.
Other elements are also found in steel slag, but in much smaller concentrations, expressed in ppm (parts per million, or $\mathrm{mg} \mathrm{kg}^{-1}$ ). Those elements are chromium ( $\mathrm{Cr}$ ), zinc ( $\mathrm{Zn}$ ), barium $(\mathrm{Ba})$, strontium $(\mathrm{Sr})$, copper $(\mathrm{Cu})$, zircon $(\mathrm{Zr})$, vanadium $(\mathrm{V})$, niobum $(\mathrm{Nb})$, lead $(\mathrm{Pb})$, nickel $(\mathrm{Ni})$, tin (Sn), molybdenum (Mo), rubidium $(\mathrm{Rb})$, arsenic (As), cadmium (Cd), uranium $(\mathrm{U})$, bromium $(\mathrm{Br})$, cerium (Ce), cobalt (Co), lanthanum (La), ytirum (Y), thorium (Th), bismuth (Bi), gallium (Ga).

Those elements are quite numerous and varied. Although the amount is small (trace), they also must be considered in applying steel slag for agriculture. If they turn into available forms and are absorbed by plants, they will pose a danger to humans that consume. This factor causes steel slag in Indonesia can be classified as a hazardous toxic material. A further research is needed to answer this assumption.

Outside the field of agriculture, there have been many studies concerning the minimization of the harmful effects of toxic elements in steel slag. In the field of construction of buildings, roads, and bridges, for example. The effect of heavy metals in steel slag on the environment is minimized by limiting the contact of materials containing steel slag with water or by cutting off the inflow and outflow of water in layers constructed using steel slag (Sas, 2015).

\section{Utilization of Steel Slag in Agriculture}

Steel slag has been used in agriculture in various countries such as Japan, Germany, the United States, Korea, China and others. They use steel slag as lime and fertilizer. The $\mathrm{Ca}$ and $\mathrm{Mg}$ content in steel slag makes this material function as lime in increasing soil $\mathrm{pH}$ and as as fertilizer in contributing those two essential nutrients. The Si content in steel slag is also used to increase the Si content in the soil. The element $\mathrm{Si}$ is not an essential nutrient, but as a non-essential nutrient. Si functions to increase the efficiency of the photosynthetic process and increase plant resistance to diseases in 
Gramineae plants such as rice, corn and sugarcane (Matichenkov and Calvert, 2002). The element Si (in silicates form in steel slag) also functions as an ameliorant, help in releasing retained $\mathrm{P}$ in Andisols (Qafoku et al., 2004).

The benefits of steel slag for lowland rice in Japan have been proven since 1955. The Ministry of Agriculture, Forestry and Fisheries of Japan then designated it as Si fertilizer (Ma and Takahashi, 2002) and still continues to use it as fertilizer (Ito, 2015). China and Korea have also used steel slag as Si fertilizer for lowland rice. There is a very good response from sugarcane and other crops due to the application of steel slag to the soil causing it to be used commercially as Si fertilizer by sugarcane plantations in Hawaii and Brazil (Gascho, 2001; Clemente et al., 2019).

The presence of Si in steel slag makes this material can be used as fertilizer, supplying $\mathrm{Si}$ for Gramineae (Ito, 2015 and Suwarno, 2010). However, the function of Si in the silicate form in the soil is more important due to it can act as an ameliorant, improves some reactions in providing P nutrients.

\section{Utilization of Steel Slag in Indonesia}

Steel slag in Indonesia has been used in several fields, although is still limited in research sector. The research has actually covered various aspects related to the potential of steel slag as a fertilizer, lime and ameliorant. Pot experiments were carried out on soybeans (Glycine max L. Merr.) and sorghum (Sorghum vulgare Pers.) in Ultisols limed with steel slag and calcite to achieve the $\mathrm{pH}$ of 5.5, 6.0, and 6.5. The results showed that liming with steel slag had a better effect on soybean and sorghum production than liming with $\mathrm{CaCO}_{3} /$ calcite (Suwarno, 1999).

Another pot experiment was carried out to evaluate the effect of guano phosphate combined with steel slag and dolomite on petsay (Brassica chinensis L) on Andisols and compared with Fused Magnesium Phosphate (FMP) and Super Phosphate (SP) fertilizers combined with dolomite. Guano phosphate, FMP, SP, steel slag and dolomite were applied to reach $\mathrm{pH}$ 6.5. Guano phosphate was much more effective when combined with steel slag than when combined with dolomite. The production of petsay from the combination of guano phosphate and steel slag was not significantly different from that of the combination of dolomite with FMP and SP fertilizers (Suwarno, 1999).

Pot experiments were also carried out to compare the effect of the combination of guano phosphate with steel slag and guano phosphate with calcite on sorghum plants grown on Ultisols. The experimental results showed that both steel slag and calcite increased the effecttiveness of guano phosphate. Guano phosphate is also more effective when combined with steel slag than when combined with calcite (Suwarno, 2002).

Research used steel slag as lime has been carried out by Suwarno (2010) on Andisols for petsay (Brassica chinensis L.) showed that the application of steel slag could increase the $\mathrm{pH}$ to 6.5 and showed improvement growth and production of petsay, better than soil. treated with high doses of $\mathrm{CaMg}\left(\mathrm{CO}_{3}\right)_{2}$ or dolomite, due to the dolomite reduced the availability of $\mathrm{B}$ and $\mathrm{Mn}$ in the soil and in plant.

The effect of steel slag on rice plants has also been carried out by several researchers. Research on steel slag as Si fertilizer for lowland rice (Oryza sativa L.) was carried out on Entisols with low Si content (134 mg kg-1). The results showed that steel slag can increase the production of pithy grains (Suwarno and Goto, 1997). The pot research was carried out with peat soil to evaluate the use of steel slag as $\mathrm{Si}$ fertilizer for lowland rice of IR 64. The application of steel slag to peat soil increases the availability of $\mathrm{Si}, \mathrm{Ca}, \mathrm{Mg}$, and increases soil $\mathrm{pH}$, but decreases the availability of $\mathrm{Fe}, \mathrm{Cu}$, and Zn (Suwarno, 2002). The provision of greenhouses was also carried out by Banjarnahor et al. (2015) and found that steel slag increased plant height, number of vegetative and 
generative tillers and reduced the percentage of empty grain.

Field research related to the use of steel slag as Si fertilizer for lowland rice of the IR 64 variety on peat soil was conducted in Sanggau Regency, West Kalimantan, which showed that steel slag increased the production of dry milled rice grain by up to $65-96 \%$. The residual effect of the provision of steel slag was also felt up to the second and third plants as reported by Setiko et al. (2015) who informed that the provision of steel slag still increased the maximum number of tillers, productive tillers and yields of rice crops until the third planting season on peat soil.

The effect of steel slag has also been investigated on peat soils and perennial crops. Steel slag is used as a peat soil repair agent in industrial forest plantations in Siak District for Acacia cracicarpa. The provision of steel slag significantly increased the growth and production of Acacia cracicarpa wood with the optimum dose for each tree was $1000 \mathrm{~g}$. The research was also conducted in the PTPN IV Panai Jaya oil palm plantation, North Sumatra. These plantations located in peatland areas/Histosols were used to examine the use of steel slag as an ameliorant and obtained the results that steel slag can increase $\mathrm{pH}$ and the ability of the soil to absorb water, prevent hydrophobicity (Winarna, et al, 2016).

There has been quite a lot of research on steel slag, has not yet made the steel slag usable in Indonesia due to is still hampered by Government Regulation No. 85 of 1999 which classifies steel slag as hazardous and toxic materials that can directly or indirectly damage and endanger the environment, health and survival of humans and other living things.

\section{Steel Slag as Ameliorant in Variable Charge Soils of Andisols and Ultisols}

The use of steel slag that has been reported by many researchers is as lime to increase soil $\mathrm{pH}$, and as fertilizer to increase the content of $\mathrm{Ca}, \mathrm{Mg}$ and $\mathrm{Si}$ in the soil. Apart from this function, there is another role of steel slag that has not been widely discussed, its potential as an ameliorant in Andisols to release retained $\mathrm{P}$, and in Ultisols to release fixed P.

Andisols and Ultisols are classified as variable charged soils that are rich in amphoteric charges with reactive surfaces. In fact, variable-charged soils have a wide spectrum of morphology, mineralogy, chemistry, physics, biology and genetic characteristics. The term variable charge is used to describe inorganic or organic components which charge depends on soil $\mathrm{pH}$ and ionic concentration. It also depends on the composition of carboxyl, phenolic, and amino groups of organic matter and surface hydroxyl groups of iron (Fe) and aluminum (Al) oxides, allophane and imogolite of mineral materials.

High phosphate retention in Andisols ( $85 \%$ or higher), is a prerequisite for Andisols as can be seen from the andic soil properties in the Soil Taxonomy (Soil Survey Staff, 2014) and the diagnostic horizon of andic in the World Reference Base (Deckers et al., 2001). The P retention was positively correlated with the content of allophane, Al soluble in oxalate (Alo) and Alo + Feo or half of Fe soluble in oxalate (Van Ranst et al., 2004). The P retention is a limiting factor in Andisols, causes $P$ nutrient is limited in this soil.

Andisols retain large amounts of phosphorus quickly but release it slowly. make availability of $P$ is low. The results of various studies showed that the surface reactivity of Andisols to available phosphorus $\left(\mathrm{PO}_{4}\right)^{-}$can be reduced by adding colloids that have a low affinity in retaining $\left(\mathrm{PO}_{4}\right)^{-}$, or by adding other anions that can compete with $\left(\mathrm{PO}_{4}\right)^{-}$(in the reactive groups of organic matter and minerals in Andisols. The ameliorant can be calcium silicate, volcanic ash, and the organic matter (Van Ranst et al., 2017). One source of calcium silicate is steel slag.

The application of steel slag can increase the negative charge in Andisols. Each hydrolysis step produces silicate anions which can compete with the phosphate anion or 
$\left(\mathrm{H}_{2} \mathrm{PO}_{4}{ }^{-}\right)$thereby releasing the adsorbed $\mathrm{H}_{2} \mathrm{PO}_{4}$ - to be available. The reaction of silicate hydrolysis in steel slag is described in Van Ranst (1995) as follows:

$$
\begin{aligned}
& \mathrm{SiO}_{4}^{-4}+\mathrm{H}_{2} \mathrm{O} \rightarrow \mathrm{SiO}_{3}(\mathrm{OH})^{-3}+\mathrm{OH}^{-} \\
& \mathrm{SiO}_{3}(\mathrm{OH})^{-3}+\mathrm{H}_{2} \mathrm{O} \rightarrow \mathrm{SiO}_{2}(\mathrm{OH})_{2}{ }^{-2}+\mathrm{OH}^{-} \\
& \mathrm{SiO}_{2}(\mathrm{OH})_{2}^{-2}+\mathrm{H}_{2} \mathrm{O} \rightarrow \mathrm{SiO}(\mathrm{OH})_{3}+\mathrm{OH}^{-} \\
& \mathrm{SiO}(\mathrm{OH})_{3}^{-}+\mathrm{H}_{2} \mathrm{O} \rightarrow \mathrm{SiO}(\mathrm{OH})_{4}+\mathrm{OH}^{-}
\end{aligned}
$$

The reaction steps described the releasing a number of silicate anions that can replace the adsorbed phosphate anions, which also adding some $\mathrm{OH}$ - anions which can increase the soil $\mathrm{pH}$. This process is the advantage of amelioration with steel slag, due to increasing the $\mathrm{pH}$ in a variable charged soil will increase the cation exchange capacity. The increasing of available $\mathrm{P}$ after the addition of silicates can also due the increasing of soil $\mathrm{pH}$ ( $\mathrm{Ma}$ and Takahashi 1990). The increase $\mathrm{pH}$ contributes to the reduction in $\mathrm{P}$ retention which indicated that the ligand exchange with the complex on the allophanic surface. The shift in the $P$ retention reaction associated with the change of the fast phase to the slow $P$ retention phase, indicated by the change in soil $\mathrm{pH}$.

The similar thing also happened to Ultisols. Phosphate in Ultisols is fixed by positively charged of $\mathrm{Al}$ and/or $\mathrm{Fe}$. The Pfixation itself is understood as the transformation of the soluble $\mathrm{P}$ into the insoluble $\mathrm{P}$, in the soils with high concentration of iron and aluminum oxides and hydroxides. The transformation makes $\mathrm{P}$ unavailable. Anions such as silicates and carbonates can compete with phosphates in Ultisols anion exchange sites, thereby increasing the availability of phosphate in the soil solution. Amelioration with lime is an effort that can be done to provide carbonate anions into the soil. Amelioration with steel slag is an attempt to provide silicate and carbonate anions to release the fixed $\mathrm{P}$ to become available.

Research related to the effect of steel slag as an ameliorant on Andisols and Ultisols has been carried out by several researchers showing that steel slag can improve several soil chemical parameters. Steel slag combined with rice husk bokashi can also improve several biological and physical parameters of the soil. The results of research by Devnita et al. (2017b) showed that steel slag given together with rice husk bokashi can reduce $\mathrm{P}$ retention and increase available P.

Steel slag combined with rice husk bokashi can also improve soil biological and physical parameters. Devnita et al. (2017b) showed that the Andisols developed from the eruption of Mt. Tangkuban Parahu, Mt. Patuha and Mt. Tilu reduced the $P$ retention by giving separately steel slag (as a source of silicates and carbonates), rock phosphate (as a source of phosphate), and rice husk bokashi (as a source of organic matter). In this study, $\mathrm{P}$ retention was reduced by as much as $10 \%$ in Andisols derived from Mt. Tangkuban Parahu, and $12 \%$ in Andisols derived from Mt. Patuha and Mt. Tilu.

Steel slag pulverized into microparticles and treated in Ultisols did not show a decrease in P fixation, but the availability of $\mathrm{P}$ increased significantly from 9 to $12 \mathrm{mg} \mathrm{kg}^{-1}$. Another parameter that increase were availability of basic cations such as $\mathrm{Ca}, \mathrm{Mg}$ and $\mathrm{K}$, each respectively of $1.5,0.12$ and $0.15 \mathrm{cmol} \mathrm{kg}-1$ (Devnita et al., 2019).

Steel slag combined with rice husk bokashi also interacted to increase available $\mathrm{P}$ (from 10 ppm to up to $70 \mathrm{ppm}$ ), and decreased $\mathrm{P}$ retention independently by $8 \%$ (from 92 to 84\%) after incubation for 1 month (Devnita et al., 2017a). The soil physical parameter was also improved by increasing permeablitu from 3 to $18 \mathrm{~cm} \mathrm{~h}^{-1}$.

\section{CONCLUSION}

Steel slag which is a by-product of iron refining in the steel industry has benefits for agriculture, due to have some elements or compounds that can be used as fertilizers and ameliorants. As a fertilizer, the content of $\mathrm{Ca}$, $\mathrm{Mg}$ and $\mathrm{P}$ add macro nutrients in the soil. The content of $\mathrm{Fe}$ in steel slag can also add micro 
nutrients. The presence of Si also increases the non-essential nutrients needed by Gramineae plants.

As an ameliorant, $\mathrm{CaO}$ and $\mathrm{MgO}$ compounds in steel slag serve as lime which can increase soil $\mathrm{pH}$. Silicate compounds in steel slag also make this material function as an ameliorant in variable charge soils of Andisols and Ultisols. They can reduce $P$ retention and $P$ fixation thereby increasing available $P$.

The use of steel slag for agriculture has been widely carried out in various countries in the world such as Japan, the United States and Germany. However, in Indonesia, steel slag is still used for research purposes, not yet widely used in farmer application. The presence of heavy metals in steel slag even in very small amounts makes the Indonesian government designate it as a hazardous toxic material. More intensive research is needed to answer the question of how much steel slag can be harmful if applied in agriculture. The potential availability of this material is actually quite large considering that Indonesia has a steel factory such as Krakatau Steel which of course has a by-product of steel slag in its production process, and will be useful if it is used in the agricultural sector.

\section{REFERENCES}

Banjarnahor, B. J., Sarifuddin, \& K. S. Lubis. 2015. Pengaruh pemberian beberapa amelioran terhadap sifat kimia tanah gambut Dataran Tinggi Toba dan pengaruhnya terhadap pertumbuhan dan produksi tanaman padi (Oryza sativa L.). Jurnal Agroekoteknologi. 6 (1): 146152.

Bing, L., T. Biao, M. Zhen, C. Hanchi and L. Hongbo. 2019. Physical and chemical properties of steel slag and utilization technology of steel slag at home and abroad. IOP Conference Series: Earth and
Environmental Science. 242 (2019): 032012.

Clemente, P. R. A., B. F. A. de Almeida, D. H. de A.B., A.L.J. Silva, V.S.G. da Silva, \& L. Endres. 2019. Morphological changes in sugarcane as a function of metallurgic slag and gypsum. Journal of Agricultural Science 11(14): 291 - 297.

Das, B., S. Prakash, P. S. R. Reddy, and V. N. Misra. 2007. An overview of utilization of slag and sludge from steel industries. Resources, Conservation and Recycling. 50 (1): 40-57.

Deckers, J., P. Driessen, F. Nachtergaele, \& 0. Spaargaren. 2001. World reference base for soil resources - in a nutshell. European Soil Bureau Research Report. 7:173-181.

Devnita, R., R. Hudaya, R. Sudirja, A. Setiawan, M. F. Rosana and H. Hazarika. 2017a. Remediation of volcanic ash soil in related to soil erodibility against the heavy rainfall. In Hazarika, H., M. Kazama, W. F. Lee (eds.). Geotechnical Hazards from Large Earthquakes and Heavy Rainfalls. Springer. Japan. p. 619 629.

Devnita, R., R. Sudirja, R. Hudaya, dan M. F. Rosana. 2017b. Amelioration of volcanic soils in improving soil chemical characteristics. Academic Journal of Science. 07(02):1-10.

Devnita, R. 2019. Soil chemical, physical and biological characteristics of andisols as affected by the amelioration of steel slag and rice husk bokashi. IOP Conf. Ser.: Earth Environ. Sci. 393: 012046

Gascho, G. J. 2001. Chapter 12 Silicon Sources for agriculture. In Datnoff, L. E. et. al. (Eds.). Studies in Plant Science Volume 8. p: 197-207. 
Ito, K. 2015. Steel making slag for fertilizer usage. Nippon Steel \& Sumitomo Metal Technical Report No. 109:130-136.

Ma, J. and E. Takahashi. 1990. The effect of silicic acid on rice in a P-deficient soil. Plant and Soil. 126: 121-125.

Matichenkov, V. V. and Calvert, D.V. 2002. Silicon as a beneficial element for sugarcane. Journal American Society of Sugarcane Technologists. 22:21-30.

Nippon Slag Association. 1978. Chemical Characteristics of Iron and Steel Slag.

http://www.slg.jp/e/slag/characte r.html.

Qafoku, N. P., E. Van Ranst, A. Noble and G. Baert. 2004. Variable charge soils, their mineralogy, chemistry and management. Advances in Agronomy. 84:157-213.

Sas, W., A. Głuchowski, M. Radziemska, J. Dzięcioł, and A. Szymański. 2015. Environmental and geotechnical assessment of the steel slags as a material for road structure. Materials Basel. 8(8): 4857-4875.

Seti'en, J., D. Hern'andez, and J. J. Gonzalez. 2009. Characterization of ladle furnace basic slag for use as a construction material. Construction and Building Materials. 23 (5): 1788-1794.

Setiko, P. H., Suwarno, \& A. Hartono. 2015. Pengaruh residu terak baja terhadap sifat kimia tanah gambut dan hasil padi sawah. Jurnal Tanah dan Iklim. 3(9):127-136.

Soil Survey Staff. 2014. Keys to Soil Taxonomy. $12^{\text {th }}$ ed. Natural Resources Conservation Service. Washington D.C.

Suwarno. 1999. Utilization of steel slag as liming material for acid tropical soils. In Proceedings of International Seminar on Toward Sustainable Agriculture in Humid Tropics Facing 21 st Century, University of Lampung, Bandar Lampung. p: 293-305.

Suwarno. 2002. Utilization of steel slag in wetland rice cultivation on peat soil. In Proceedings of the International Symposium on Land Management and Biodiversity in South East Asia. Bali. p: 211-215.

Suwarno. 2010. Pemanfaatan steel slag Indonesia di bidang pertanian. Jurnal Tanah dan Lingkungan. 12 (1):36-41

Suwarno and I. Goto. 1997. Application of Indonesian electric furnace slag as acid soil amendment. Proceedings of International Seminar on Development of Agribusiness and Its Impact on Agricultural Production in South East Asia (DABIA). Nodai Center for International Program, Tokyo University of Agriculture, Tokyo. p: 395-402.

Van Ranst, E., S. R. Utami, J. Vanderdeelen and J. Shamsuddin. 2004. Surface reactivity of andisols on volcanic ash along the Sunda Arc crossing Java Island, Indonesia. Geoderma. 123:193-203.

Van Ranst, E., N. P. Qafoku, A. Noble and R. Xu. 2017. Variable charge soils: mineralogy and chemistry. Encyclopedia of Soil Science. 3: 2432-2439.

Van Ranst, E. 1995. Rational soil management in the humid tropics. Meded. Zit.K. Academic Overseas Wet. 40: 209233.

Winarna, I. Pradiko, M. Syarovy dan F. Hidayat. 2016. Perbaikan sifat-sifat dan pencegahan hidrofobisitas tanah gambut di perkebunan kelapa sawit melalui aplikasi terak baja. J. Pen. Kelapa Sawit. 24(1):39-46. 
Wright, R.N. 2011. Relevant aspects of carbon and low-alloy steel metallurgy. In Wire Technology Process Engineering and Metallurgy. Butterworth-Heinemann. Oxford. p: 175-197.

Yildirim, I. Z. and Prezzi, M. 2011. Chemical, mineralogical, and morphological properties of steel slag. Advanced in Civil Engineering. 2011: 1 - 13. 